\title{
Median raphe cyst of the penis: a case report and review of the literature
}

\author{
M. M. Aarif Syed ${ }^{*} \mathbb{D}$, Bibush Amatya and Seema Sitaula
}

\begin{abstract}
Background: A defect in embryological development or closure of median raphe may lead to formation of cyst(s) anywhere in the midline from glans to anus. These cysts are referred to as median raphe cysts, an uncommonly encountered clinical condition. The cyst is generally solitary, with the penile shaft being the most common location, with average size of around $1 \mathrm{~cm}$. The diagnosis is mostly clinical and confirmed histologically. We report a case of a patient with a rare histological variant of median raphe cyst and provide a focused review on presentation, histopathology, and management.

Case presentation: A 29-year-old unmarried Nepali man presented to our clinic with an asymptomatic, solitary, soft, translucent, nontender cystic lesion of about 1-cm diameter at the ventral aspect of glans penis, close to the meatus, that had been noticed at the age of 3 and was nonprogressive for the past 15 years. Ultrasonography demonstrated an isoechoic cystic lesion at the tip of the penis, separated from the urethra, and lying entirely within the mucosa without any evidence of solid component, septation, or vascularity. On the basis of clinical and ultrasonographic findings, a diagnosis of median raphe cyst of the penis was made. The cyst was excised with the patient under local anesthesia, and there was no evidence of recurrence in 2 years of follow-up. The histopathological examination with Hematoxylin and eosin staining showed the cyst wall was lined partly by ciliated pseudostratified columnar epithelium and partly by columnar epithelium with apical mucin.
\end{abstract}

Conclusions: Median raphe cyst is an uncommon, mostly asymptomatic condition in young patients. The cyst may occur anywhere along the midline from glans to anus. The diagnosis is clinical with histological confirmation.

Excision is the treatment of choice with minimal chance of recurrence.

Keywords: Median raphe cyst, Penis, Scrotum, Perineum, Excision

\section{Background}

The male external genitalia develops from the genital tubercle, which contains two urethral folds and the scrotal swellings that fuse in the midline to form the scrotum. The center of fusion is marked by the penile, scrotal, and perineal raphe. A defect in embryological development or closure of the median raphe may lead to formation of cyst(s) in the midline, and hence the name median raphe cyst (MRC). However, there are other theories also explaining the pathogenesis [1]. Mermet first described the condition in 1895 [2]. The location of the cyst varies anywhere in the midline from glans to anus [3-5]. MRC is an uncommon benign lesion, mostly presenting to

* Correspondence: syedmmaarif@gmail.com

Department of Dermatology and Venereology, Institute of Medicine,

Tribhuvan University, Maharajgunj, Kathmandu, Nepal surgeons, urologists, or pediatricians and sometimes to dermatologists [5-7]. Hence, it becomes imperative for dermatologists to know this condition and differentiate it from other lesions of penis, scrotum, or perineum. We report a case of a patient with a rare histological variant of MRC. We also review the clinical presentation, pathogenesis, histopathology, investigations, complications, and management of MRC of the penis. The primary databases searched for the review were PubMed, Google Scholar, the Cochrane Library, and Hinari. The search terms included "median raphe cyst," "genitoperineal raphe cyst," "mucoid cyst of penis," "apocrine cystadenoma of penis", "hydrocystoma of penis," "epidermoid cyst of penis," and "parameatal cyst."

(C) The Author(s). 2019 Open Access This article is distributed under the terms of the Creative Commons Attribution 4.0 International License (http://creativecommons.org/licenses/by/4.0/), which permits unrestricted use, distribution, and reproduction in any medium, provided you give appropriate credit to the original author(s) and the source, provide a link to the Creative Commons license, and indicate if changes were made. The Creative Commons Public Domain Dedication waiver (http://creativecommons.org/publicdomain/zero/1.0/) applies to the data made available in this article, unless otherwise stated. 


\section{Case presentation}

A 29-year-old unmarried Nepali man presented to our clinic with a complaint of soft, painless swelling at the tip of the penis since childhood. His mother had noticed the swelling when the patient was at the age of 3 , and the swelling had increased in size for a few years to reach its present dimension. However, the swelling had been nonprogressive for the past 15 years. He had no complaints of pain, itching, burning, tenderness, discharge, trauma, or oozing. The lesion did not interfere with urination or penile erection. He did not have any history of congenital anomaly, any medical illness, or similar lesions in family members. The patient's only concern was cosmetic and the possibility of interference in sexual activity, because he was planning to get married soon.

His physical examination revealed a solitary, soft, translucent cystic lesion of about 2-cm diameter at the ventral aspect of the glans penis, close to the meatus, but not involving the margins of the urethral orifice (Fig. 1). The overlying mucosa was shiny, whereas the surrounding mucosa was normal. The cyst was soft and nontender on palpation. The urethral opening was not obstructed, and examination of other regions of the penis, scrotum, and perineal region were unremarkable. No palpable inguinal lymphadenopathy was seen. The results of the patient's urinalysis and hemogram were normal. Ultrasonography (USG) of the cyst was advised, which demonstrated an isoechoic cystic lesion at the tip of the penis (Fig. 2). There was no evidence of a solid component, septation, or vascularity within the cyst seen by USG (Fig. 2). The urethra was separated from the cyst, which was entirely within the mucosa (Fig. 2). On the basis of clinical and USG findings, a diagnosis of MRC of the penis was made.

The cyst was excised with the patient under local anesthesia (Fig. 3a, b). During excision, the cyst ruptured, releasing the mucinous content. The whole specimen was sent for histopathological examination. Hematoxylin and eosin (H\&E) staining showed the cyst wall was lined partly by ciliated, pseudostratified columnar epithelium and partly by columnar epithelium with apical mucin (Fig. 4a, b). The lamina propria showed mild chronic inflammatory infiltrates. No features of dysplasia or malignancy were noted. IHC could not be done, owing to technical and financial reasons. The patient was followed for 1 year. The site of the excision healed without any residual effect (Fig. 3b). There were no issues related to urination or sexual activities. Recurrence was not observed during the 2-year follow-up period.

\section{Discussion and review}

\section{History}

MRC is a rare congenital entity. Earlier literature consisting of case reports are mainly from Japan $[1,8-11]$. However, Asarch et al. (USA) compiled six cases reported as early as 1979 [7]. Nagore et al. described a case series of five patients from Spain in 1998 [6]. In

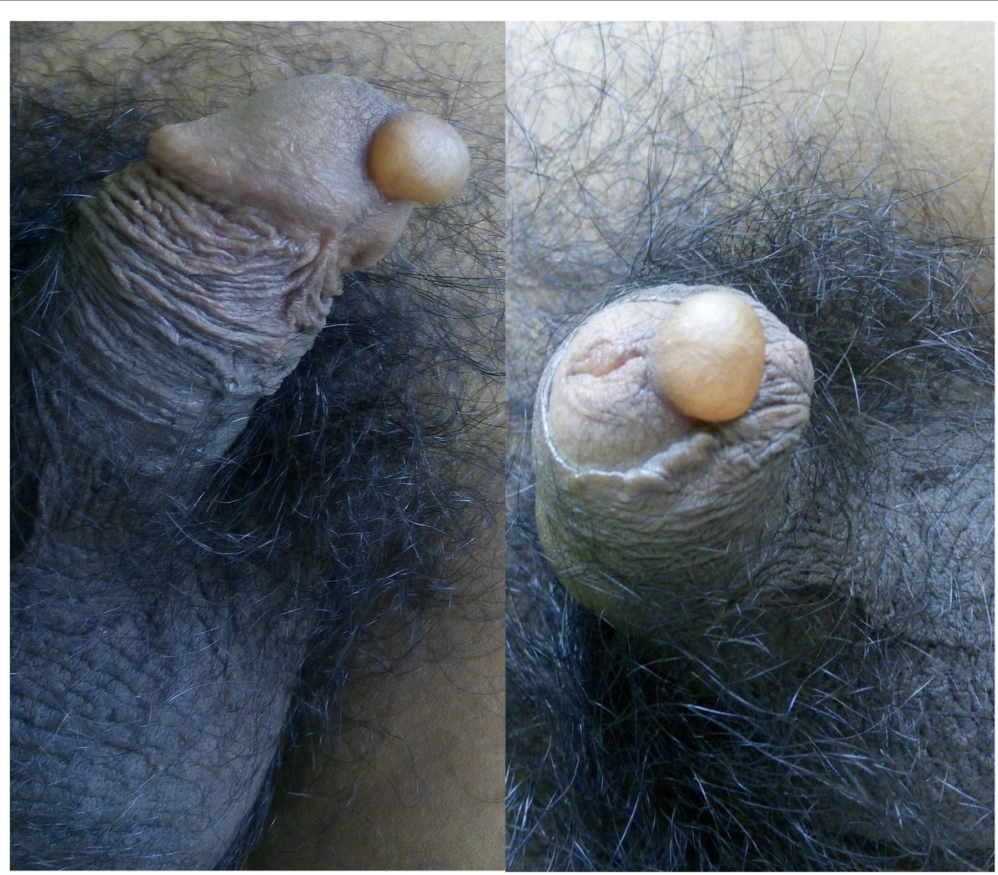

Fig. 1 A solitary, soft, translucent cystic lesion of about 1-cm diameter seen at the ventral aspect of glans penis, close to the meatus 


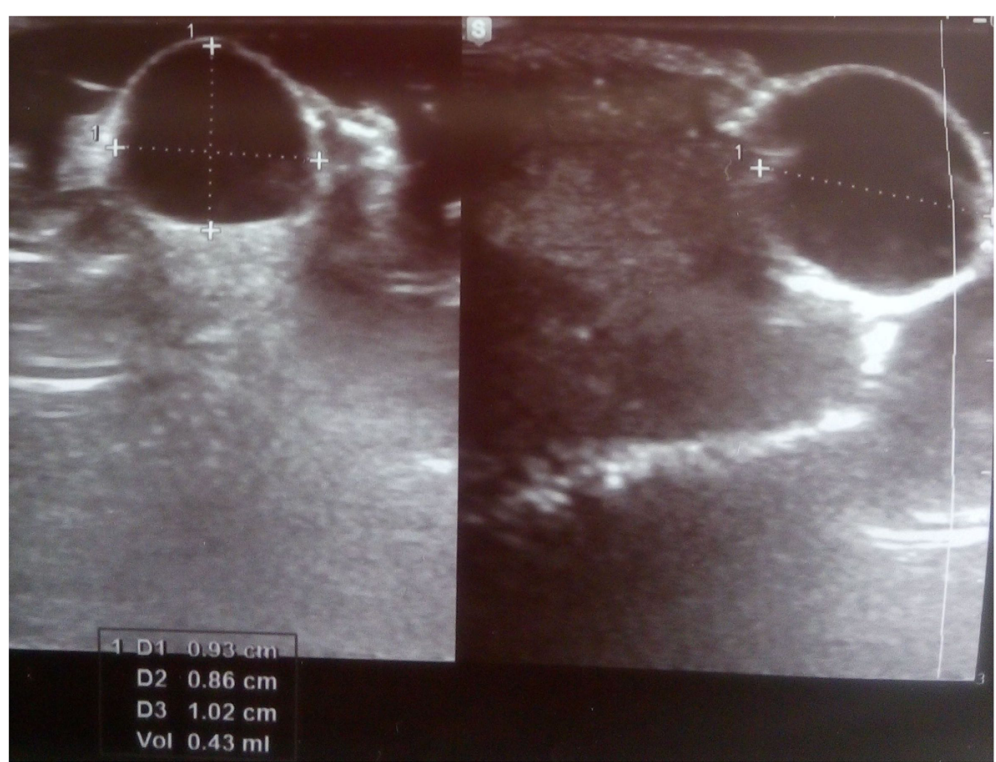

Fig. 2 Ultrasonography of the cyst showing a well-circumscribed isoechoic lesion without any extension to the urethra

recent decades, cases have been reported from other parts of the world as well (also see Table 1).

Several terms have been used in the past to describe the condition. It includes genitoperineal cyst of median raphe [19, 20], mucoid cyst of penis [21], apocrine cystadenoma/hydrocystoma of penis [22, 23] and epidermoid cysts [24]. A cyst close to the meatus has been referred to as parameatal cyst $[1,25,26]$. However, in the view of authors, the term that could be synonymous to MRC, is genitoperineal cyst of median raphe. It's still debatable if all these entities are actually same or different [15]. One fact that unites these conditions is that they all reflect developmental defect in male genitalia during embryogenesis. Mucoid cyst may result from faulty closure of penoscrotoperineal raphe with sequestration of ectopic urethral mucosa [21]. An apocrine cystadenoma/ hydrocystoma has bluish hue on clinical examination, while pathological details would reveal focal areas of decapitation secretion in epithelial lining, along with a myoepithelial layer [22, 23]. An epidermoid cyst may result due abnormal closure of the median raphe during embryogenesis or, rarely, following mechanical implantation in acquired cases [27]. A parameatal cyst may arise due to obstruction of paraurethral duct or anomalous fusion of urethra [28].

\section{Clinical presentation}

The cyst is most commonly noticed in the first decade of life; however, because of the condition being asymptomatic, the patient often presents during second to third decades of life. Our patient's mother first noticed the cyst when he was at the age of 3 , but the patient

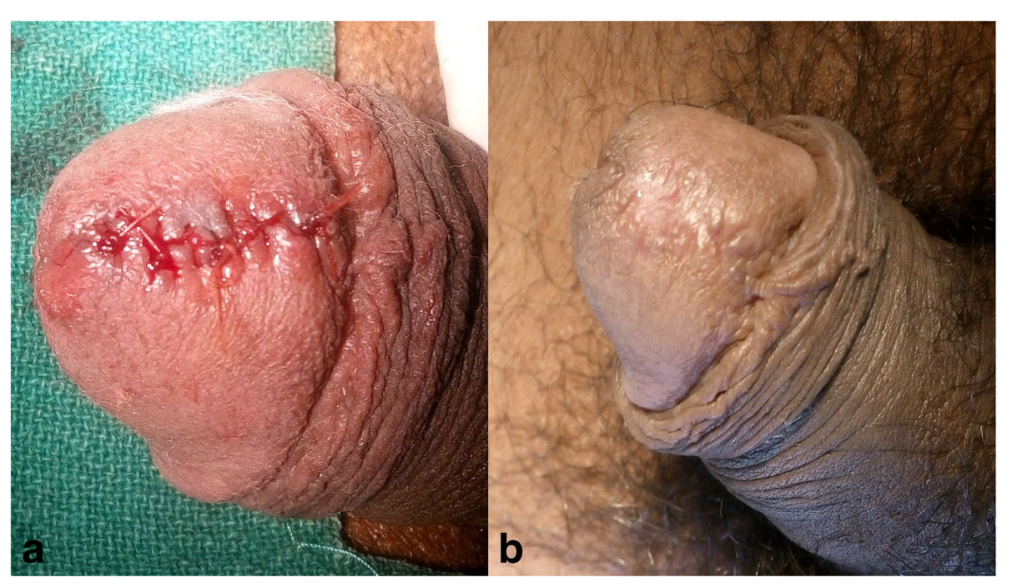

Fig. $\mathbf{3}$ a and $\mathbf{b}$ Glans penis immediately following excision of the cyst and after healing, leaving no residual effect 


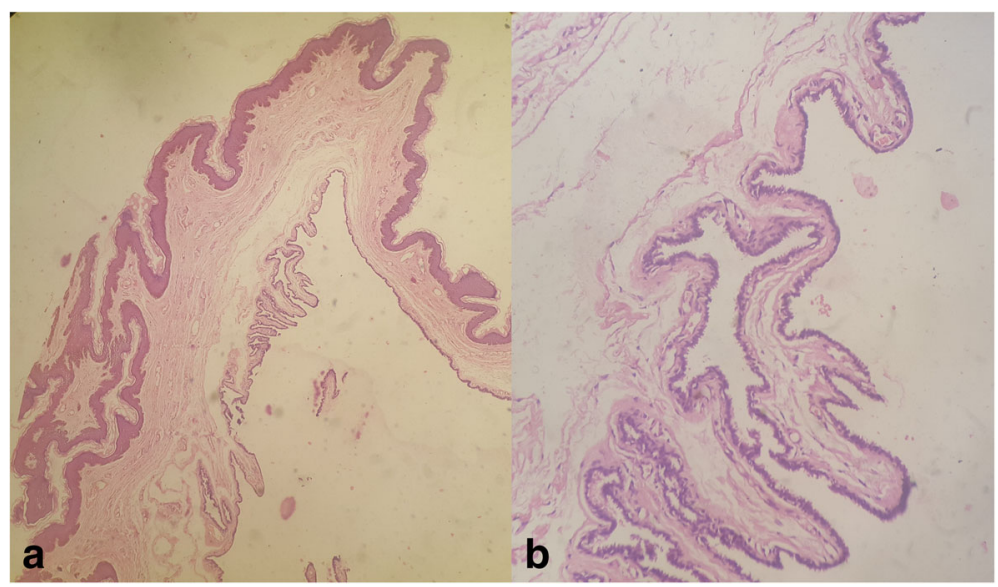

Fig. 4 a Hematoxylin and eosin (H\&E) stain (original magnification $\times 200$ ) showing cystic cavity lined externally by normal skin and internally by pseudostratified columnar epithelium. $\mathbf{b}$ H\&E stain (original magnification $\times 400$ ) showing cyst wall lined partly by ciliated pseudostratified columnar epithelium and partly by columnar epithelium

came for medical advice at the age of 29 years, when he was planning to get married. Shao et al. mentioned the mean age of presentation to be 26.7 years with a bimodal age distribution at approximately $1-10$ years and $21-40$ years [5]. Navalón-Monllor et al. found a slightly lower mean age (24.6 years) with similar bimodal age characteristics, having higher presentation during the first and third decades of life [4] (also see Table 2).

Our patient was asymptomatic, and the cyst had ceased to grow for more than a decade. MRCs are mostly asymptomatic $[3-5,7,31]$ and grow proportionately with body size [33]. Though asymptomatic, MRC has the potential to cause psychological embarrassment and discomfort [31]. Parameatal cysts are more likely to

Table 1 Reports with two or more than two cases of median raphe cyst

\begin{tabular}{llll}
\hline Authors & Year & No. of cases & Location \\
\hline Asarch et al. [7] & 1979 & 6 & USA \\
Otsuka et al. [11] (genitoperineal raphe) & 1990 & 160 & Japan \\
Little et al. [12] & 1992 & 2 & USA \\
Pellicé i Vilalta and Luelmo i Aguilar [13] & 1997 & 2 & Spain \\
Nagore et al. [6] & 1998 & 5 & Spain \\
Otsuka et al. [1] & 1998 & 3 & Japan \\
López-Candel et al. [14] & 2000 & 2 & Spain \\
Dini et al. [15] & 2001 & 2 & Italy \\
Navarro et al. [16] & 2009 & 2 & Spain \\
Verma [17] & 2009 & 2 & India \\
Shao et al. [5] & 2012 & 55 & Taiwan \\
Matsuyama et al. [3] & 2016 & 23 & Japan \\
Navalon-Monllor et al. [4] & 2017 & 28 & Spain \\
Kumar et al. [18] & 2017 & 2 & India \\
\hline
\end{tabular}

give rise to symptoms of urinary obstruction [4, 5, 34]. These symptoms are limited to dysuria, urinary frequency, or deflected urinary stream $[3,16,35]$. Pain, if present, is an indication of infection $[4,5,12]$. Rarely, hematuria, hematospermia [5], and difficulty in sexual function $[34,36]$ may be presenting complaints. A cyst near the anal region is mistaken for hemorrhoids [37]. The most common reason for consultation is aesthetic $[4,15]$. The more distal the cyst and earlier the age at presentation, the greater the chances of it being symptomatic [5]. A case of appearance of MRC in the shaft of the penis following intense, prolonged sexual intercourse has been described [38].

The cyst is generally solitary [3-5], sometimes double [3], and rarely presents as a chain of cystic swellings along the median raphe $[4,10,33,39]$. The chain of cysts gives a cordlike appearance and has been described as canaliform MRCs $[17,29,40]$. Another variant is the presence of cysts within the raphe canal, which is an

Table 2 Individual cases of median raphe cyst reported with age $<1$ year and $>60$ years

\begin{tabular}{lll}
\hline Authors & No. of cases & Age of presentation \\
\hline Verma [17] & 2 & 3 months and 6 months \\
Shibagaki et al. [9] & 1 & 4 months \\
Wang et al. [20] & 1 & 4 months \\
Park et al. [29] & 1 & 8 months \\
Kumar et al. [18] & 1 & 9 months \\
Scelwyn [30] & 1 & 62 years \\
Sagar et al. [31] & 1 & 65 years \\
Dini et al. [15] & 1 & 67 years \\
Navarro et al. [16] & 1 & 68 years \\
Bhasin et al. [32] & 1 & 76 years \\
\hline
\end{tabular}


elongated tract along the median raphe [41-44]. Coexistence of a cystic-type lesion and canaliform variant in different regions has also been reported [37]. Videodermatoscopy can help confirm the presence of a true canal [43]. The cyst is always obvious on the surface; however, a case of MRC was reported from the United Kingdom in which MRC presented as nonvisible palpable swelling that was confirmed on USG and magnetic resonance imaging (MRI) [45]. Another variation in presentation could be the beginning of the condition with a single lesion with subsequent appearance of more cysts [46]. The cyst very rarely may have central umbilication, giving rise to differential diagnosis of molluscum contagiosum [47].

The cysts are generally translucent, and the penile shaft is the most common location [3-5]. However, many authors have separately defined parameatal urethral cysts, whose numbers exceed those of cysts in any other location [3, 28, 48, 49]. Consideration of parameatal cyst as a separate condition or a form of MRC needs more discussion in the scientific community. We tend to agree making parameatal the most common variant of MRC. The cyst may have a bluish hue [6], which is more a characteristic of cystadenoma/hydrocystoma of the penis. Pigmented cysts appearing as brown-black in color due to presence of melanocytes and melanin pigment in the epithelial lining have also been reported $[10,46,50]$. Multiple areas are rarely involved. The majority of the cysts do not reach size in excess of $1 \mathrm{~cm}[4,5]$. However, Matsuyama et al. [3] reported that about $70 \%$ of the patients in their study had size less than $0.5 \mathrm{~cm}$. Scrotal cysts tend to be larger than cysts elsewhere [5]. In our patient, the size of the cyst was about $1 \mathrm{~cm}$, which made it larger than the mean observed size of these cysts. MRCs with sizes in excess of $2 \mathrm{~cm}$ have also been reported [16, 32, 50]. A comparative analysis of a few clinical features of MRC as reported in three large reviews is presented in Table 3. MRC has to be differentiated from a number of conditions. A differential diagnosis by location is given in Table 4 .

\section{Pathogenesis}

A debate on the pathogenesis of MRC has also seen varied views. The cyst may represent an embryological developmental anomaly of male genitalia or a defect in closure of the median raphe. The genital tubercle, two urethral folds and the scrotal swellings, give rise to male external genitalia. The scrotal swellings fuse in the midline to form the scrotum, which leaves a permanent surface marking in the form of median raphe. An incomplete closure of the genital or urethral fold gives rise to epithelial rest. The rest may develop into either a cyst or a canal, depending on the presence or absence of an opening on skin surface [54]. A cyst can appear even after primary closure from split-off outgrowths of embryonic epithelium [54]. A theory that also finds support is "tissue trapping," in which epithelial rests may get buried during midline fusion and evolve into a cyst or canal [12]. Autologous transplant of skin tissue specimens has shown the development of cysts at the transplant sites, lending credibility to the tissue-trapping theory [55]. Shiraki, on the basis of a study of nine cases of parameatal cyst of glans penis, proposed the occlusion of paraurethral ducts resulting in cyst formation as an explanation [48]. A congenital obliteration of these ducts hampered the physiological drainage and led to development of cysts [48]. Infection and trauma are acquired contributory factors in the obstruction [49]. Light and electron microscopic findings of Otsuka et al. support this theory [1]. Cole and Helwig proposed an alternative, stating that these cysts could be the result of sequestered ectopic periurethral glands of Littre [21]. However, strong evidence in support of this explanation is still lacking.

\section{Investigations}

The diagnosis is mostly clinical and is confirmed histologically. As in our patient, USG shows an isoechoic cystic lesion [34, 45]. It can help to rule out vascularity and continuity to overlying or underlying structures. However, it has a very limited role in diagnosis and is not frequently ordered. The use of MRI is also not encouraged and reveals low T2-weighted signal of a soft tissue lesion without any appreciable contrast enhancement [45]. Like USG, MRI also helps in determining the anatomical extent of the cyst [16]. A urethrogram will not show any communication between the cyst and urethra [8].

\section{Histopathology/IHC}

The cyst in our patient was unilocular, which is the condition most frequently encountered. However, multilocular cysts can also be seen [16]. The pathogenetic mechanism and type of tissue trapped explain the tissue lining $[6,7]$. Trapping of the proximal and distal urethra would result in pseudostratified and stratified squamous epithelial lining, respectively. If the periurethral glands are trapped, they will form a glandular lining of cyst. Shoa et al. published an extensive report based on histopathological findings in 55 cases of MRCs [5]. They classified MRCs into four groups, depending on the type of epithelial lining of the cyst wall:

1. Urethral: Lined by pseudostratified columnar epithelium, such as the urothelium

2. Epidermoid: Lined by squamous stratified epithelium

3. Glandular: Lined by urethral epithelium with interspersed glandular structure 
Table 3 Clinical characteristics of median raphe cyst in three large reviews

\begin{tabular}{llll}
\hline & Shao et al. [5] & Matsuyama et al. [3] & Navalon-Monllor et al. [4] \\
\hline No. of cases & $55^{\text {a }}$ & 23 & 28 \\
Cyst size range & $0.2-2.1 \mathrm{~cm}$ & 0.1 to $>1 \mathrm{~cm}$ & $0.5-3.5 \mathrm{~cm}$ \\
Mean size of cyst & $0.88 \mathrm{~cm}$ & NA & $1.1 \mathrm{~cm}$ \\
$\begin{array}{l}\text { Cyst location } \\
\text { Parameatal }\end{array}$ & $19(33.9)$ & $\mathrm{b}$ & $8(28)$ \\
Glans penis & $4(7.1)$ & - & - \\
Penile shaft & $24(42.9)$ & $11(47.8)$ & $10(36)$ \\
$\begin{array}{l}\text { Scrotum/perineum } \\
\text { Prepuce }\end{array}$ & $2(3.6)$ & $2(8.7)$ & $2(7)$ \\
Multiple areas & $7(12.7)$ & - & $3(11)$ \\
Corona/balanic frenulum & & $4(17.4)$ & $2(7)$ \\
Symptoms & & $6(26.1)$ & $3(11)$ \\
Asymptomatic & $15(27.3)$ & $19(82.6)$ & $22(79)$ \\
Symptomatic & & $4(17.3)$ & $4(21)$ \\
\hline
\end{tabular}

MRC Median raphe cyst, NA Not available

Data in parentheses are percentages

${ }^{a} 55$ Patients with 56 MRCs

${ }^{\mathrm{b}}$ Authors have taken parameatal urethral cysts (PUCs) as a separate category and compared them with MRCs. The PUC group had 46 patients, and the MRC group had 23 patients. Thus, PUCs formed in $66 \%$ of their cases

4. Mixed: Lined by more than one type of epithelium, such as urethral epithelium with squamous metaplasia or mucinous cells, or all the three coexisting

We would like to extend this classification and add two more categories: ciliated and pigmented. The ciliated type is characterized by the presence of ciliated cells interspersed with pseudostratified $[16,26,47,56]$ or columnar $[31,57,58]$ epithelium. The pigmented variant appears brown-black in color due to the presence of melanocytes and melanin pigment in the epithelial lining $[10,46,50]$. Pigment granules can become evident with Fontana-Masson stain [50]. Though case reports on these two groups always claimed them to be rare findings, we would like to challenge this claim. Ciliated cysts have been reported more frequently than glandular variant (see Table 4). The epidermoid type, too, is uncommonly reported (see Table 4) [5], but it has never been referred to as rare. Some authors attribute ciliated cysts

Table 4 Differential diagnosis of median raphe cyst by location

\begin{tabular}{ll}
\hline Location & Differential diagnosis \\
\hline Glans penis & $\begin{array}{l}\text { Urethral diverticulum, capillary/cavernous } \\
\text { hemangioma, glomus tumor, leiomyoma [51] }\end{array}$ \\
Shaft & $\begin{array}{l}\text { Steatocystoma, molluscum contagiosum, } \\
\text { trichilemmal cyst [52], dermoid and } \\
\text { epidermoid cysts, lipoma }\end{array}$ \\
Scrotum & Steatocystoma, calcinosis cutis \\
Perineum & Cowper gland cyst, lipoma, epidermoid cyst \\
Perianal & Hemorrhoids, perianal polyp, pilonidal cyst, \\
& hidradenitis, teratomas [53] \\
\hline
\end{tabular}

to an additional abnormality of embryological development [47], whereas others refer to it as a result of metaplastic changes in the urothelium [58]. In our extensive literature search, we could only find three cases of pigmented variant $[10,46,50]$, which in our view makes them truly rare.

Unal et al. [56], in their compilation of cases of ciliated cysts, mentioned six cases, including their own, as documented in the literature. Perhaps they missed the case reported by Navarro et al. in 2009 [16] and the one reported by Amaranathan et al. in 2013 [57] (also see Table 4). We extend this list and include these two cases. We further include our patient's case as well, which also showed ciliated, pseudostratified epithelium, thus taking the number of total reported cases to nine. In Table 5, we compile the histopathological findings of 2 large reviews of MRC and 29 individual case reports/series documented separately as one group.

IHC has been undertaken in several case reports (Table 6). The most consistent staining is seen with cytokeratin 7 , strongly indicative of urethral origin of the cyst (Table 6). Positive cytokeratin 13 lends further support. Carcinoembryonic antigen positivity has also been regularly reported, except by Persec et al. [60]. Cytokeratin 20 and smooth muscle actin results remain negative.

\section{Complications}

The cyst may be secondarily infected and manifest as pain, tenderness, erythema, or pus discharge. About 16\% of patients reported by Shao et al. had infected cysts [5]. The most common organism found is Neisseria gonorrhoeae 
Table 5 Histopathological findings in 2 large reviews and a third group comprising 29 individual case reports

\begin{tabular}{|c|c|c|c|}
\hline & Shao et al. [5] & Navalon-Monllor et al. [4] & Third group \\
\hline Number of cases & $56^{\mathrm{a}}$ & 28 & 29 \\
\hline \multicolumn{4}{|c|}{ Type of epithelium } \\
\hline Urethral & $31(55.4)$ & $15(54)$ & $\begin{array}{l}{[37,44]} \\
{[6]^{b} \times 5} \\
{[7]^{b} \times 5} \\
\text { Total: } 12 / 29(41.3)\end{array}$ \\
\hline Epidermoid & $3(5.4)$ & $2(7)$ & $\begin{array}{l}{[29,33,42]} \\
\text { Total: } 3 / 29(10.3)\end{array}$ \\
\hline Glandular & $2(3.4)$ & & $\begin{array}{l}{[1]^{c} \times 3} \\
\text { Total: } 3 / 29(10.3)\end{array}$ \\
\hline Mixed & $20(35.7)$ & $11(39)$ & $\begin{array}{l}{[7,15,20,34,40,45,59-61]} \\
{[18]^{d} \times 2} \\
\text { Total: } 11 / 29(37.9)\end{array}$ \\
\hline \multicolumn{4}{|l|}{ Rare variants } \\
\hline Ciliated & - & - & {$[16,30,31,47,56-58,62]+$ our patient } \\
\hline Pigmented & - & - & {$[10,46,50]$} \\
\hline
\end{tabular}

[63, 64]. Infection with Trichomonas vaginalis can also occur, but it is rare [65]. However, these are case reports of infection of the median raphe rather MRC. Staphylococcus aureus infecting MRC of the scrotum and penis has been noted in old case reports $[54,66]$. Infection of MRC has been uncommonly documented in recent decades. The culture of the cystic content can help confirm the infective organism. Infection is generally a phenomenon noticed after sexual intercourse. The cyst may also be traumatized by other means and become infected. Urinary obstruction, if due to a parameatal cyst, does not lead to urethritis. MRCs never communicate with the urethra; however, recently, a case of an epidermoid variant traversing the corpus cavernosum has been reported [67]. Another case of MRC in the scrotum was found to mimic a serous tumor and was associated with cryptorchidism [68]. A few very unusual cases of MRC reported in the literature are compiled in Table 7.

\section{Treatment}

Spontaneous resolution has been reported [3, 9, 28]. Observation is another option when the cyst is small

Table $6 \mathrm{IHC}$ results in various case reports

\begin{tabular}{|c|c|c|c|c|c|c|c|}
\hline & $\begin{array}{l}\text { Dini et al. } \\
\text { (2001) [15] }\end{array}$ & $\begin{array}{l}\text { Cardoso et al. } \\
(2005)[61]\end{array}$ & $\begin{array}{l}\text { Sagar et al. } \\
(2006)[31]\end{array}$ & $\begin{array}{l}\text { Koga et al. } \\
\text { (2007) [62] }\end{array}$ & $\begin{array}{l}\text { Persec et al. } \\
\text { (2013) [60] }\end{array}$ & $\begin{array}{l}\text { Deliktas et al. } \\
\text { (2015) [34] }\end{array}$ & $\begin{array}{l}\text { Çalışkan et al. } \\
\text { (2015) [59] }\end{array}$ \\
\hline CK7 & + & + & + & + & + & + & + \\
\hline CK13 & + & + & & & & & \\
\hline CK2O & - & - & - & - & - & - & - \\
\hline CEA & + & + & + & + & - & + & + \\
\hline Anti-S100 & & - & + & - & - & & + \\
\hline SMA & & & - & - & - & & - \\
\hline Desmin & & & - & & & & \\
\hline EMA & & + & + & + & + & & \\
\hline HMFG-1 & & - & & & & & \\
\hline CAM5.2 & + & & & & & & \\
\hline GCDFP-15 & & & & - & & & + \\
\hline
\end{tabular}

Abbreviations: CEA Carcinoembryonic antigen, CK Cytokeratin, EMA Epithelial membrane antigen, HMFG Human milk fat globulin, SMA Smooth muscle actin, GCDFP-15 Gross cystic disease fluid protein-15 
Table 7 A few very unusual cases of median raphe cyst reported in the literature

\begin{tabular}{llll}
\hline Authors & Title & Reference. no. \\
\hline Bhasin et al. & Giant median raphe prepuceal cyst in an elderly male. & [32] \\
Takahashi et al. & Congenital median raphe cysts: coexistence of cystic lesions and canal-like lesions. & [37] & [38] \\
Sharkey et al. & Postcoital appearance of a median raphe cyst. & [67] & [68] \\
Yu et al. & A case of epidermoid median raphe cyst traversing the corpora cavernosa. & \\
Hara et al. & Median raphe cyst in the scrotum, mimicking a serous borderline tumor, associated & \\
\end{tabular}

and the child is asymptomatic [12]. Because the cyst mostly remains symptom-free, some patients deny any active treatment [6]. If left untreated, the cyst may rupture on its own and heal uneventfully [12]. Aspiration of the cyst is associated with recurrence $[5,33,48]$. Marsupialization or unroofing is not recommended, because it may lead to gaping sinus [48]. However, marsupialization has been found to be effective in treating canals [41]. Median raphe canals have also been treated with incision followed by electrodessication [7]. Excision followed by primary closure remains the treatment of choice $[3-5,7]$ and provides cosmetically acceptable results. When the cyst lies in the prepuce, circumcision can also be performed [32, 57]. A giant cyst hanging at the frenulum has been treated with excision and repair by frenuloplasty [49].

Excision is associated with excellent results, with no evidence of recurrence in 6 months [36], 1 year [34, 45], and 4 years [56] of follow-up. In a case series with six patients, Asarch et al. noted recurrence in one of the patients after 5 years, and the cyst was reexcised with no subsequent recurrence [7]. One of the patients of Shao et al. developed a fistula following excision [5]. In a retrospective study spanning 14 years, Matsuyama et al. did not identify a single case of recurrence following treatment [3].

\section{Conclusions}

MRC is an uncommon, mostly asymptomatic condition seen in young patients. The cyst may occur anywhere along the midline from the glans to the anus. The diagnosis is clinical with histological confirmation. Excision is the treatment of choice with minimal chance of recurrence.

\section{Acknowledgements}

None to declare.

\section{Authors' contributions}

MMAS and SS were involved in clinical diagnosis and treatment of the patient. MMAS, BA, and SS collected and assembled the data and participated in literature review. MMAS and BA designed the manuscript. All of the authors read and approved the final version of the manuscript.

\section{Funding}

The authors declare that there was no source of funding.
Availability of data and materials

Data sharing is not applicable to this article, because no data were generated or analyzed during the study. All data (clinical and histopathological) gathered for this study are included in this published article.

\section{Ethics approval and consent to participate}

Case reports do not require ethical approval; however, the general informed consent process includes obtaining patient approval for anonymous use of relevant clinical and surgical information and photographs.

\section{Consent for publication}

Written informed consent was obtained from the patient for publication of this case report and any accompanying images. A copy of the written consent is available for review by the Editor-in-Chief of this journal.

\section{Competing interests}

The authors declare that they have no competing interests.

Received: 12 November 2018 Accepted: 27 May 2019

Published online: 14 July 2019

\section{References}

1. Otsuka T, Ueda Y, Terauchi M, Kinoshita Y. Median raphe (parameatal) cysts of the penis. J Urol. 1998;159(6):1918-20.

2. Mermet P. Congenital cysts of the genitoperineal raphe. Rev Chir. 1895;15: 382-435.

3. Matsuyama S, Matsui F, Yazawa K, Matsumoto F, Shimada K, Matsuoka K. Long-term follow-up of median raphe cysts and parameatal urethral cysts in male children. Urology. 2017;101:99-103.

4. Navalon-Monllor V, Ordono-Saiz MV, Ordono-Dominguez F, Sabater-Marco V, Pallas-Costa Y, Navalon-Verdejo P. Median raphe cysts in men: presentation of our experience and literature review. Actas Urol Esp. 2017;41(3):205-9.

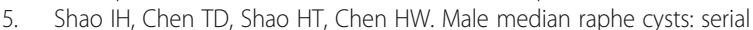
retrospective analysis and histopathological classification. Diagn Pathol. 2012;7:121.

6. Nagore E, Sanchez-Motilla JM, Febrer MI, Aliaga A. Median raphe cysts of the penis: a report of five cases. Pediatr Dermatol. 1998;15(3):191-3.

7. Asarch RG, Golitz LE, Sausker WF, Kreye GM. Median raphe cysts of the penis. Arch Dermatol. 1979;115(9):1084-6.

8. Sasagawa I, Nakada T, Yamaguchi O, Shiraiwa Y. Different types of median raphe cysts in the penis. Int Urol Nephrol. 1992;24(2):187-91.

9. Shibagaki N, Ohtake N, Furue M. Spontaneous regression of congenital multiple median raphe cysts of the raphe scroti. Br J Dermatol. 1996;134(2): 376-8.

10. Urahashi J, Hara H, Yamaguchi Z, Morishima T. Pigmented median raphe cysts of the penis. Acta Derm Venereol. 2000;80(4):297-8.

11. Otsuka T, Terauchi M. Cysts of the genito-perineal raphe: a study of 160 reported cases. Jap J Plast Reconstruct Surg. 1990;33:777-83.

12. Little JS Jr, Keating MA, Rink RC. Median raphe cysts of the genitalia. J Urol. 1992;148(6):1872-3.

13. Pellicé i Vilalta C, Luelmo i Aguilar J. Cysts of the median raphe (prepuce and perineum): brief contribution [in Spanish]. Actas Urol Esp. 1997;21(8): 803-5.

14. López-Candel E, Roig Alvaro J, López-Candel J, Fernández Dozagarat S, Soler J, Hernández Bermejo JP, et al. Median raphe cysts of the perineum in childhood [in Spanish]. An Esp Pediatr. 2000;52(4):395-7. 
15. Dini M, Baroni G, Colafranceschi M. Median raphe cyst of the penis: a report of two cases with immunohistochemical investigation. Am J Dermatopathol. 2001;23(4):320-4.

16. Navarro HP, Lopez PC, Ruiz JM, Martinez Sanchiz C, Cha SH, Sanchez AS, et al. Median raphe cyst: report of two cases and literature review. Arch Esp Urol. 2009:62(7):585-9.

17. Verma SB. Canal-like median raphe cysts: an unusual presentation of an unusual condition. Clin Exp Dermatol. 2009;34(8):e857-8.

18. Kumar P, Das A, Savant SS, Barkat R. Median raphe cyst: report of two cases. Dermatol Online J. 2017;23(2):15

19. Sanchez-Conejo-Mir J, Moreno-Gimenez JC, Camacho-Martinez F. International dermatosurgery: genitoperineal cyst of the median raphe. J Dermatol Surg Oncol. 1984;10(6):451-4

20. Wang $\mathrm{C}$, Lee J, Huang $\mathrm{H}$. Median raphe canals of the genitoperineum. Dermatol Sinica. 1996;14(2):95-9.

21. Cole LA, Helwig EB. Mucoid cysts of the penile skin. J Urol. 1976;115(4):397-400.

22. Ahmed A, Jones AW. Apocrine cystadenoma: a report of two cases occurring on the prepuce. Br J Dermatol. 1969;81(12):899-901.

23. Powell RF, Palmer $\mathrm{CH}$, Smith EB. Apocrine cystadenoma of the penile shaft Arch Dermatol. 1977;113(9):1250-1.

24. Papali AC, Alpert SA, Edmondson JD, Maizels M, Yerkes E, Hagerty J, et al. A review of pediatric glans malformations: a handy clinical reference. J Urol. 2008;180(4 Suppl):1737-42.

25. Lantin PM, Thompson IM. Parameatal cysts of the glans penis. J Urol. 1956; 76(6):753-5

26. Koga S, Arakaki Y, Matsuoka M, Ohyama C. Parameatal urethral cysts of the glans penis. Br J Urol. 1990;65(1):101-3.

27. Suwa M, Takeda M, Bilim V, Takahashi K. Epidermoid cyst of the penis: a case report and review of the literature. Int J Urol. 2000;7(11):431-3.

28. Willis HL, Snow BW, Cartwright PC, Wallis MC, Oottamasathien S, deVries C. Parameatal urethral cysts in prepubertal males. J Urol. 2011;185(3):1042-5.

29. Park CO, Chun EY, Lee JH. Median raphe cyst on the scrotum and perineum. J Am Acad Dermatol. 2006;55(5 Suppl):S114-5.

30. Scelwyn M. Median raphe cyst of the perineum presenting as a perianal polyp. Pathology. 1996;28(2):201-2.

31. Sagar J, Sagar B, Patel AF, Shak DK. Ciliated median raphe cyst of perineum presenting as perianal polyp: a case report with immunohistochemical study, review of literature, and pathogenesis. World Scientific Journal. 2006; 6:2339-44.

32. Bhasin S, Loach R, Sharma G, Gorka V. Giant median raphe prepuceal cyst in an elderly male. Int Surg J. 2016;2016(2):1018-20

33. Redman J. Median raphe cysts of the perineum and scrotum. Revista Peruana Urol. 2009;18(2):111-2.

34. Deliktas $\mathrm{H}$, Sahin $\mathrm{H}$, Celik Ol, Erdogan O. Median raphe cyst of the penis. Urol J. 2015;12(4):2287-8

35. Lu CC. A median raphe cyst of the glans penis in a 10-year old boy with urination complaints. Incont Pelvic Floor Dysfunct. 2010;4(1):23.

36. Arrabal-Martin M, Jimenez-Pacheco A, Arrabal-Polo M, Arias-Santiago S. Median raphe cyst of the penis: diagnosis and therapeutic approach [abstract]. J Am Acad Dermatol. 2012;66(4):AB38.

37. Takahashi M, Watanabe T, Sato K, Ohno M, Yamada K, Takezoe T, et al. Congenital median raphe cysts: coexistence of cystic lesions and canal-like lesions. Open J Pediatr. 2013;3(3):2.

38. Sharkey MJ, Grabski WJ, McCollough ML, Berger TG. Postcoital appearance of a median raphe cyst. J Am Acad Dermatol. 1992;26(2 Pt 1):273-4.

39. Bandyopadhyay D. Canaliform median raphe cyst. Indian J Dermatol Venereol Leprol. 2018;84(1):108.

40. Shin S, Hann SK, Kim DY. A case of multiple canaliform median raphe cysts showing a mixed type lining of epithelium: a case report and review of the literature. Ann Dermatol. 2016;28(3):398-9.

41. Golitz LE, Robin M. Median raphe canals of the penis. Cutis. 1981;27(2):170-2.

42. Krauel L, Tarrado X, Garcia-Aparicio L, Lerena J, Sunol M, Rodo J, et al. Median raphe cysts of the perineum in children. Urology. 2008;71(5):830-1.

43. LaCarrubba F, Tedeschi A, Francesconi L, Micali G. Canal versus cysts of the penile median raphe: advancing diagnostic methods using videodermatoscopy. Pediatr Dermatol. 2010;27(6):667-9.

44. Ravasse P, Petit T, Pasquier CJ. Perineal median raphe canal: a typical image. Urology. 2002;59(1):136.

45. Parnham AS, Freeman A, Kirkham A, Muneer A. An unusual swelling in the male perineum. BMJ Case Rep. 2015;2015:bcr2014206199.
46. Colmenero I, Sastre N, de Prada I, Hernandez-Martin A. Pigmented cyst of the median raphe of the scrotum in a boy [in Spanish]. Actas Dermosifiliogr. 2009;100(7):633-4

47. Romani J, Barnadas MA, Miralles J, Curell R, de Moragas JM. Median raphe cyst of the penis with ciliated cells. J Cutan Pathol. 1995;22(4):378-81.

48. Shiraki IW. Parametal cysts of the glans penis: a report of 9 cases. J Urol. 1975;114(4):544-8

49. Hill JT, Ashken MH. Parameatal urethral cysts: a review of 6 cases. Br J Urol. 1977:49(4):323-5.

50. Hitti IF, Vuletin JC, Rapuano J. Giant median raphe cyst of the penis with diffuse melanosis of its epithelial lining. Urol Int. 1989:44(2):121-4.

51. English JC 3rd, Laws RA, Keough GC, Wilde JL, Foley JP, Elston DM. Dermatoses of the glans penis and prepuce. J Am Acad Dermatol. 1997;37(1):1-24. quiz 5-6.

52. Madan S, Joshi R. Trichilemmal cyst of the penis in a paediatric patient. Sultan Qaboos Univ Med J. 2015;15(1):e129-32.

53. Dahan $H$, Arrive L, Wendum D, Docou le Pointe H, Djouhri H, Tubiana JM. Retrorectal developmental cysts in adults: clinical and radiologichistopathologic review, differential diagnosis, and treatment. Radiographics. 2001:21(3):575-84

54. Neff J. Congenital canals and cysts of the genito-perineal raphe. Am J Surg. 1936:31(2):308-15

55. Epstein WL, Kligman AM. Epithelial cysts in buried human skin. AMA Arch Dermatol. 1957;76(4):437-45

56. Unal B, Bassorgun C, Karanis M, Elpek G. Perianal median raphe cyst: a rare lesion with unusual histology and localization. Case Rep Dermatol Med. 2015;2015:3.

57. Amaranathan A, Sinhasan SP, Dasiah SD. Median raphe cysts of the prepucial skin, with triple histological linings: a case report and review of the literature. J Clin Diagn Res. 2013;7(7):1466-8.

58. Acenero MJ, Garcia-Gonzalez J. Median raphe cyst with ciliated cells: report of a case. Am J Dermatopathol. 2003;25(2):175-6.

59. Çalışkan S, Sungur M, Baş Y. Median raphe cyst of the scrotum in an adult patient. SM J Urol. 2015;1(2):1009.

60. Persec Z, Persec J, Sovic T, Rako D, Bacalja J, et al. Median raphe cyst-clinical report and immunohistochemical analysis [abstract]. J Clin Exp Dermatol Res. 2013:4(Suppl):S6.

61. Cardoso R, Freitas JD, Reis JP, Tellechea O. Median raphe cyst of the penis Dermatol Online J. 2005:11(3):37.

62. Koga K, Yoshida Y, Koga M, Takeshita M, Nakayama J. Median raphe cyst with ciliated cells of the penis. Acta Derm Venereol. 2007;87(6):542-3.

63. Bernfeld WK. Gonorrhoea in the median raphe of the penis: case report and a survey of the literature. Br J Vener Dis. 1961;37:210-3.

64. Rice JS. Gonorrhea in median raphe of penis. Arch Dermatol. 1963:87(3):395.

65. Pavithran K. Trichomonal abscess of the median raphe of the penis. Int J Dermatol. 1993:32(11):820-1.

66. Oshin DR, Bowles WT. Congenital cysts and canals of the scrotal and perineal raphe. J Urol. 1962;88(3):406-8.

67. Yu A, Capolicchio JP. A case of epidermoid median raphe cyst traversing the corpora cavernosa. Can Urol Assoc J. 2017;11(3-4):E119-21.

68. Hara N, Kawaguchi M, Koike H, Takahashi K. Median raphe cyst in the scrotum, mimicking a serous borderline tumor, associated with cryptorchidism after orchiopecxy. Int J Urol. 2004;11(12):1150-2.

\section{Publisher's Note}

Springer Nature remains neutral with regard to jurisdictional claims in published maps and institutional affiliations.

Ready to submit your research? Choose BMC and benefit from:

- fast, convenient online submission

- thorough peer review by experienced researchers in your field

- rapid publication on acceptance

- support for research data, including large and complex data types

- gold Open Access which fosters wider collaboration and increased citations

- maximum visibility for your research: over $100 \mathrm{M}$ website views per year

At $\mathrm{BMC}$, research is always in progress.

Learn more biomedcentral.com/submissions 